p-ISSN: $2338-4794$

e-ISSN: 2579-7476

Vol.9. No. 1 Januari-April 2021

\title{
PENGARUH LINGKUNGAN KERJA DAN DISIPLIN KERJA TERHADAP PRODUKTIVITAS KERJA KARYAWAN BAGIAN OPERATOR SPBU BEKASI PT PERTAMINA RETAIL
}

\author{
Bayu Setiawan 1) \\ 1) Mahasiswa Program Studi Manajemen FE UNKRIS \\ Nuridin ${ }^{2)}$ \\ 2) Dosen Program Studi Manajemen FE UNKRIS \\ Alamat: Kampus UNKRIS, Jatiwaringin Jakarta Timur \\ Email : h.nuridin58@gmail.com
}

\begin{abstract}
The purpose of this study was to determine the effect of work environment and work discipline on work productivity of employees at the Bekasi SPBU Operators Section, PT Pertamina Retail. The research method used is descriptive qualitative and quantitative analysis, the analysis model used linear regression either partially or simultaneous. The population in this study were 52 employees of the Bekasi SPBU Operator Section, Ahmad Yani. The sampling technique in this study used a saturated sampling technique, all members of the population were sampled totaling 52 employees. The result work environment and work discipline have a positive and significant effect on the work productivity of employees of PT Pertamina Retail's Bekasi SPBU Operators Section, either partially or simultaneous.
\end{abstract}

Keywords: Work environment, work discipline and work productivity

\section{PENDAHULUAN}

Perusahaan merupakan sebuah organisasi yang menjalankan kegiatan bisnis baik berupa barang maupun jasa, yang dimana organisasi ini berkembang dengan keuntungan yang diperoleh. Adanya era globalisasi dan teknologi yang semakin maju, perusahaan lebih dituntut dapat menghadapi persaingan-persaingan pasar baik pasar dalam negeri maupun pasar luar negeri. Dan setiap perusahaan berusaha untuk lebih meningkatkan kualitas kinerjanya agar dapat unggul dalam persaingan global. Persaingan tersebut muncul adanya perkembangan teknologi yang semakin pesat, yang akan berdampak pada kualitas kinerja karyawan.

Menangani karyawan yang kualitasnya di bawah standart adalah dengan pendekatan, salah satu cara untuk meminimalisir penurunan kualitas kinerja karyawan, perusahaan dapat mengadakan program pengembangan terhadap sumber daya manusia. Karena sumber daya manusia merupakan peran terpenting dalam setiap kegiatan organisasi. Pengembangan sumber daya manusia dianggap salah satu cara yang paling efektif dalam meningkatkan kualitas kinerja, produktivitas perusahaan, dan juga daya saing terhadap perusahaanperusahaan lain.

Usaha dalam peningkatan produktivitas karyawan perlu dilakukan bagi semua perusahaan, baik perusahaan swasta maupun perusahaan di bawah kendali negara (BUMN). Peningkatan produktivitas dilakukan agar sumber daya manusia yang dimiliki dapat digunakan secara efektif dan efisien sehingga tidak terjadi penggunaan biaya yang sia-sia dan target perusahaan dapat dicapai dengan maksimal serta meminimalisir kerugian. Dapat diartikan bahwa karyawan sebagai 
aset yang bernilai bagi perusahaan wajib untuk dijaga, dipelihara, dan dipertahankan keberadaannya karena kemajuan perusahaan dapat dilihat dari produktivitas kerja yang diberikan oleh karyawan.

Produktivitas kerja adalah kemampuan karyawan dalam berproduksi dibandingkan dengan input yang digunakan, seorang karyawan dapat dikatakan produktif apabila mampu menghasilkan barang atau jasa sesuai dengan diharapkan dalam waktu yang singkat atau tepat

Menurut Komaruddin (2006) pada hakekatnya "produktivitas meliputi sikap yang senantiasa mempunyai pandangan bahwa metode kerja hari ini harus lebih baik dari metode kerja kemarin dan hasil yang dapat diraih esok harus lebih banyak atau lebih bermutu daripada hasil yang diraih hari ini".

Jika produktivitas kerja karyawan tinggi, maka karyawan mampu menunjukkan jumlah hasil yang sama dengan jumlah masukan yang lebih besar menghasilkan jumlah yang lebih besar dibanding dengan jumlah masukan. Sebaliknya jika produktivitas karyawan rendah maka karyawan tidak mampu menghasilkan hasil atau produksi yang sama bahkan tidak mampu memenuhi target yang telah ditentukan oleh perusahaan.

Faktor-faktor yang mempengaruhi prouktivitas kerja karyawan diantaranya adalah lingkungan kerja dan disiplin kerja. Ketika melakukan pekerjaan, karyawan sebagai manusia tidak dapat dipisahkan dari berbagai keadaan disekitar tempat mereka bekerja, yaitu lingkungan kerja. Selama melakukan pekerjaan, setiap karyawan akan berinteraksi dengan berbagai kondisi yang terdapat dalam lingkungan kerja.

Interaksi karyawan dengan pekerjaan dan lingkungan kerjanya menghasilkan barang atau jasa. Berdasarkan hasil kerjanya, karyawan mendapatkan imbalan yang berdampak pada meningkatnya produktivitas kerjanya.

Menurut Sedarmayanti, (2017), "Lingkungan kerja adalah keseluruhan alat perkakas dan bahan yang dihadapi, lingkungan sekitarnya di mana seseorang bekerja, metode kerjanya, serta pengaturan kerjanya baik sebagai perseorangan maupun sebagai kelompok".

Lingkungan kerja merupakan segala sesuatu yang ada disekitar karyawan pada saat bekerja baik berupa fisik maupun nonfisik yang dapat mempengaruhi karyawan saat bekerja. Jika lingkungan kerja yang kondusif maka karyawan bisa aman, nyaman dan jika lingkungan kerja tidak mendukung maka karyawan tidak bisa aman dan nyaman.

Faktor lain yang dapat mempengaruhi produktivitas kerja karyawan adalah disiplin kerja. Disiplin kerja sebagai suatu sikap menghormati, menghargai, patuh dan taat terhadap peraturan-peraturan yang berlaku, baik yang tertulis maupun tidak tertulis serta sanggup menjalankannya dan tidak menggelak untuk menerima sanksisanksinya apabila ia melanggar tugas dan wewenang yang diberikan.

Menurut Rivai (2015) disiplin kerja adalah "suatu alat yang digunakan para manajer untuk berkomunikasi dengan karyawan agar mereka bersedia untuk mengubah suatu perilaku sebagai suatu upaya untuk meningkatkan kesadaran dan kesediaan seseorang mematuhi semua peraturan perusahaan dan norma-norma sosial yang berlaku".

Disiplin kerja merupakan bentuk peraturan yang diterapkan oleh perusahaan untuk dapat dipatuhi oleh karyawan yang berupa sikap kesadaran, kerelaan dan kesedian karyawan dalam mematuhi dan menaati norma-norma sosial yang berlaku di lingkungan kerjanya.

PT Pertamina merupakan perusahaan tunggal yang mengelola 
minyak dan gas bumi di Indonesia dan memiliki beberapa anak perusahaan salah satunya PT Pertamina Retail. PT Pertamina Retail merupakan anak perusahaan yang ditugaskan untuk mengelola SPBU di Indonesia. PT Pertamina Retail merupakan salah satu perusahaan yang bergerak di bidang pendistribusian BBM atau SPBU, dimana pekerjaan serta lingkungan kerjanya sangat menuntut disiplin kerja yang tinggi dari karyawan untuk menghadapi persaingan dunia usaha SPBU yang sangat ketat. Dalam memenangkan persaingan, yang telah lebih dari 11 tahun telah dibuktikan oleh PT Pertamina Retail maka sangat menuntut perusahaan untuk terus menerus berupaya mengembangkan inovasi serta kreativitas sumber daya manusia dengan membangun etos kerja yang professional guna meningkatkan nilai tambah dan kualitas pelayanan kepada konsumen. Hal ini sesuai dengan salah satu misi Pertamina Retail yaitu meningkatkan kualitas sumber daya manusia guna menjawab tantangan perubahan jaman dan memenangkan persaingan.

Pertamina Retail, hadir untuk memenuhi pendistribusian BBM di kota Bekasi pada awal tahun 2009 tepatnya pada bulan Mei tahun 2009 Stasiun Pompa Bensin Untuk Umum (SPBU). Pertama berdiri di jalan Ahmad Yani No. 1 Bekasi dengan nomor 31.17101 yang merupakan SPBU percontohan pertamina. Seiring meningkatnya kebutuhan masyarakat akan ketersediaan BBM, maka PT. Pertamina Retail mendirikan SPBU Sumarecon Bekasi - 33.17101, dan Pondok Ungu - 33.17106. Dengan dasar infrastruktur yang kuat serta di dukung staf dan karyawan terlatih dan berpengalaman, PT Pertamina Retail maju untuk bersaing dengan SPBU - SPBU dari luar negeri (Shell dan Petronas) dan menjadi SPBU Pertamina terbaik di kota Bekasi.
Pada PT Pertamina Retail sumber daya manusia merupakan asset yang paling penting bagi organisasi, dimana pada hakekatnya berfungsi sebagai faktor penggerak bagi setiap kegiatan di dalam perusahaan. Suatu organisasi dalam melakukan aktivitasnya untuk mencapai tujuan yang diinginkan perlu adanya manajemen yang baik terutama sumber daya manusia, karena sumber daya manusia merupakan modal utama dalam merencanakan, mengorganisir, mengarahkan serta menggerakkan faktorfaktor yang ada dalam suatu organisasi.

Berdasar hasil wawancara dengan beberapa karyawan PT Pertamina Retail, adanya beberapa masalah lingkungan kerja yang terjadi seperti: 1). Beban kerja yang berlebih. 2). Tanggung jawab overload. 3). Adanya perilaku konsumen yang kurang baik. 4). Pekerjaan yang monoton, berulang-ulang dan tidak variatif. Semua faktor lingkungan kerja ini bisa berdampak secara psikologis yang dapat mengganggu produktivitas kerja karyawan. Faktor lain yang juga dapat mempengaruhi produktivitas kerja karyawan adalah disiplin kerja. Disiplin kerja dalam suatu perusahaan sangat diperlukan, apabila karyawan melanggar disiplin kerja maka yang terjadi adalah menurunnya hasil kerja yang didapat.

Kemudian dari segi disiplin kerja masalah yang sering terjadi di PT Pertamina Retail adalah sebagai berikut: 1). Sering terjadi keterlambatan datang kerja. 2). Nilai kompensasi yang kecil. 3). Kurangnya perhatian atasan. Adanya sanksi yang nyata.

Tujuan penelitian ini adalah untuk mengetahui pengaruh lingkungan kerja dan disiplin kerja terhadap produktivitas kerja karyawan Bagian Operator SPBU Bekasi PT Pertamina Retail. 


\section{LANDASAN TEORI}

\section{Produktivitas Kerja}

Pada dasarnya produktivitas kerja mencakup sikap mental karyawan yang memandang ke masa depan secara optimis dengan memegang keyakinan diri bahwa kehidupan hari ini adalah lebih dari hari kemarin dan hari esok adalah lebih baik dari hari ini. Pengertian produktivitas sendiri masih belum ada kesepakatan umum dari para ahli serta kriterianya dalam mengikuti petunjuk-petunjuk produktitas.

\section{Menurut Hasibuan}

mengemukakan bahwa produktivitas adalah "perbandingan antara output (hasil dengan input (masukan). Jika produktivitas naik ini hanya dimungkinkan oleh adanya peningkatan efisiensi (waktu-bahan-tenaga) dan sistem kerja, teknik produksi dan adanya peningkatan keterampilan dari tenaga kerja".

Produktivitas mengikut sertakan pendayagunaan secara terpadu sumber daya manusia dan keterampilan, barang modal, teknologi, manajemen, informasi, dan energi kepada pengembangan dan peningkatan standar hidup untuk seluruh masyarakat, melalui konsep produktivitas total. "Produktivitas mempunyai pengertian lebih luas dari ilmu pengetahuan, teknologi dan teknik manajemen, yaitu sebagai suatu sikap mental yang timbul dari motivasi yang kuat dari orang lain yang secara terus menerus berusaha meningkatkan kualitas kehidupan". (Sinungan, 2011), sedangkan menurut Simanjuntak (2011), mengemukakan bahwa Secara filosofis, "produktivitas mengandung pandangan hidup dan sikap mental yang selalu berusaha untuk meningkatkan mutu kehidupan. Keadaan hari ini harus lebih baik dari kemarin, dan mutu kehidupan besok harus lebih baik dari hari ini. Pandangan hidup dan sikap mental yang demikian akan mendorong manusia untuk tidak cepat merasa puas, akan tetapi terus mengembangkan diri untuk meningkatkan kemampuan sehingga akan dihasilkan produktivitas yang tinggi”.

Dalam upaya mengembangkan produktivitas kerja karyawan disuatu perusahaan perlu memperhatikan faktorfaktor yang mempengaruhi produktivitas kerja karyawan tersebut. Banyak faktor yang dapat mempengaruhi produktivitas kerja karyawan baik yang berhubungan dengan tenaga kerja itu sendiri maupun faktor-faktor yang berhubungan dengan lingkungan perusahaan dan kebijakan pemerintahsecara keseluruhan.

\section{Menurut Sinungan}

menyebutkan bahwa faktor-faktor yang dapat mempengaruhi produktivitas kerja adalah sebagai berikut: 1). "Tenaga kerja; Kenaikan sumbangan tenaga kerja pada produktivitas adalah karena adanya tenaga kerja yang lebih sehat, lebih terdidik danlebih giat. Produktivitas dapat meningkat karena hari kerja yanglebih pendek. Imbalan dari pengawas dapat mendorong karyawan lebih giat dalam mencapai prestasi. Dengan demikian jelas bahwa tenaga kerja berperan penting dalam produktivitas. Faktor tenaga kerja meliputi: a). Pendidikan; Pada umumnya orang yang memiliki pendidikan lebih tinggi akan mempunyai wawasan yang lebih luas terutama penghayatan akan arti pentingya produktivitas dapat mendorong pegawai yang bersangkutan melakukan tindakan yang produktif. Pendidikan, baik formal maupun informal, akan mendorong karyawan bertindak produktif. b). Disiplin; Disiplin kerja, yaitu sikap patuh, taat, dan sadar pada peraturan lembaga atau organisai. Disiplin kerja dapat membuat pekerjaan cepat terselesaikan. c). Motivasi; Motivasi, yaitu dorongan kehendak yang mempengaruhi perilaku karyawan untuk meningkatkan produktivitas kerjanya. Apabila karyawan mendapatkan motivasi, maka akan menimbulkan psikologis untuk meningkatkan dedikasi serta pemanfaatan 
potensi yang dimiliki untuk meningkatkan produktivitas kerja. d). Keterampilan dan Pengalaman; Pada aspek tertentu apabila pegawai semakin terampil dan berpengalaman, maka akan lebih mampu bekerja serta menggunakan fasilitas kerja dengan baik. Oleh karena itu tujuan perusahaan dapat dicapai. 2). Seni serta ilmu manajemen; Manajemen adalah faktor produksi dan sumberdaya ekonomi, sedangkan seni adalah pengetahuan manajemen yang memberikan kemungkinan peningkatan produktivitas. Manajemen termasuk perbaikan melalui penerapan teknologi dan pemanfaatan pengetahuan yang memerlukan pendidikan dan penelitian. 3). Modal; Modal merupakan landasan gerak suatu usaha perusahaan, karenadengan modal perusahaan dapat menyediakan peralatan bagimanusia yaitu untuk membantu melakukan pekerjaan dalam meningkatkan produktivitas kerja. Fasilitas yang memadai akan membuat semangat kerja bertambah secara tidak langsung produktivitas kerja dapat meningkat".

Menurut Sinungan (2011) manfaat dari pengukuran produktivitas kerja adalah sebagai beikut: 1). "Umpan balik pelaksanaan kerja untuk memperbaiki produktivitas kerja karyawan.

Evaluasi produktivitas kerja digunakan untuk penyelesaian misalnya: pemberian bonus dan bentuk kompensasi lainnya. 3). Untuk keputusan-keputusan penetapan, misalnya: promosi, transfer dan demosi. 4). Untuk kebutuhan latihan dan pengembangan. 5). Untuk perencanaan dan pengembangan karier. 6). Untuk mengetahui penyimpanganpenyimpangan proses staffing. 7). Untuk mengetahui ketidak akuratan informal. 8). Untuk memberikan kesempatan kerja yang adil”.

Menurut (Sutrisno, 2016), mengatakan bahwa untuk dapat mengukur produktivitas kerja, sangat diperlukan suatu indikator, yaitu:
"Kemampuan; Mempunyai kemampuan di dalam melaksanakan tugas, disini seorang karyawan sangat bergantung kepada keterampilan yang dimiliki serta profesionalisme mereka dalam bekerja. Hal ini memberikan daya untuk menyelesaikan tugas-tugas yang diembannya kepada mereka. 2 ). Meningkatkan hasil yang dicapai; Berusaha untuk meningkatkan hasil yang dicapai. Hasil merupakan salah satu yang dapat dirasakan baik oleh yang mengerjakan maupun yang menikmati hasil pekerjaan tersebut. 3). Semangat kerja; Keinginan dan kesungguhan seseorang mengerjakan pekerjaannya dengan baik serta berdisiplin untuk mencapai produktivitas yang maksimal, ini merupakan suatu usaha untuk lebih baik dari hari kemarin. 4). Pengembangan diri; Pengembangan diri dapat dilakukan dengan melihat tantangan dan harapan dengan apa yang dihadapi. 5). Mutu; Mutu merupakan hasil pekerjaan yang dapat menunjukkan kualitas kerja seorang pegawai. 6). Efisiensi; Perbandingan antara hasil yang dicapai dengan keseluruhan sumber daya yang digunakan".

\section{Lingkungan Kerja}

Lingkungan kerja menurut Nitisemito (2014), adalah "segala sesuatu yang ada disekitar pekerja dan yang dapat mempengaruhi dirinya untuk menjalankan tugas-tugas yang dibebankan". Sementara itu Robbins (2008), mendefinisikan "lingkungan kerja merupakan karakteristik yang meliputi berbagai situasi yang ada disekitar organisasi bersangkutan, baik lingkungan sosial (berupa manusia) maupun limgkungan fisik (non manusia)".

Menurut Basuki dan Susilowati (2005) lingkungan kerja adalah "segala sesuatu yang berada di lingkungan yang dapat mempengaruhi baik secara langsung maupun tidak langsung seseorang atau sekelompok orang di dalam melaksanakan 
aktivitasnya". Menurut Sedarmayanti, (2017). "Kondisi lingkungan kerja dikatakan baik atau sesuai apabila manusia dapat melaksanakan kegiatan secara optimal, sehat, aman, dan nyaman. Kesesuaian lingkungan kerja dapat dilihat akibatnya dalam jangka waktu yang lama lebih jauh lagi lingkungan-lingkungan kerja yang kurang baik dapat menuntut tenaga kerja dan waktu yang lebih banyak dan tidak mendukung diperolehnya rancangan sistem kerja yang efisien".

Berdasarkan definisi tersebut, dapat diketahui bahwa lingkungan kerja adalah disi atau keadaan yang mempengaruhi cukup besar terhadap pegawai dalam melakukan pekerjaan atau terhadap jalannya operasi perusahaan.

Secara garis besar, jenis lingkungan kerja terbagi menjadi dua, yaitu (Sedarmayanti, 2017): 1). Lingkungan Kerja Fisik; Lingkungan kerja fisik adalah semua keadaan berbentuk fisik yang terdapat disekitar tempat kerja yang dapat mempengaruhi pegawai baik secara langsung maupun tidak langsung. Lingkungan kerja fisik dapat dibagi menjadi dua kategori yaitu:

a).

Lingkungan kerja yang langsung berhubungan dengan pegawai seperti pusat kerja, kursi, meja, dan sebagainya. b). Lingkungan perantara atau lingkungan umum dapat juga disebut lingkungan kerja yang mempengaruhi kondisi manusia misalnya temparatur, kelembaban, sirkulasi udara, pencahayaan, kebisingan, getaran mekanik, bau tidak sedap, warna dan lain-lain. Untuk dapat memperkecil penguruh lingkungan fisik terhadap karyawan, maka langkah pertama harus mempelajari manusia, baik mengenal fisik dan tingkah lakunya, kemudian digunakan sebagai dasar memikirkan lingkungan fisik yang sesuai. $\quad 2$ ). Lingkungan Kerja Non Fisik; Lingkungan kerja non fisik adalah semua keadaan yang terjadi yang berkaitan dengan hubungan kerja, baik hubungan dengan atasan, maupun hubungan dengan sesama rekan kerja ataupun hubungan dengan bawahan. Perusahaan hendaknya dapat mencerminkan kondisi yang mendukung kerja sama antar tingkat atasan, bawahan maupun yang memiliki status yang sama. Kondisi yang hendaknya diciptakan adalah suasana kekeluargaan, komunikasi yang baik, dan pengendalian diri (Nitisemito, 2014). Jadi lingkungan kerja non fisik ini juga merupakan kelompok lingkungan kerja yang tidak bisa diabaikan.

Siagian (2012) menyatakan untuk terciptanya lingkungan kerja yang baik terdapat beberapa hal yang harus menjadi perhatian, antara lain: 1). "Bangunan tempat kerja. 2). Ruang kerja yang lega. $3)$. Ventilasi pertukaran udara. Terdapat tempat-tempat ibadah keagamaan. 5). Terdapat saranan angkungan khusus ataupun secara umum untuk karyawan menjadi nyaman dan mudah".

Menurut Nitisemito menyatakan terdapat indikator lingkungan kerja, antara lain: 1 ). Kebersihan; Lingkungan yang bersih dapat menimbulkan perasaan yang nyaman dan senang sehingga dapat mempengaruhi semangat kerja seseorang. Dalam setiap instansi hendaknya selalu menjaga kebersihan lingkungan kerja yang bersih akan dapat mempengaruhi kesehatan kejiwaan. Kebersihan lingkungan bukan hanya berarti kebersihan tempat kerja, tetapi jauh lebih luas daripada itu misalkan kamar kecil yang berbau tidak sedap akan menimbulkan rasa kurang menyenangkan bagi para pegawai yang menggunakan. Menjaga kebersihan pada umumnya diperlukan tugas khusus tetapi ini bukan semata-mata kewajiban dari petugas khusus tersebut. Setiap pegawai wajib ikut bertanggung jawab untuk menjaga kebersihan tempat mereka bekerja. 2). Desain kantor; Tata peralatan dalam ruang lantai yang tersedia, yang dapat mempengaruhi aktivitas ruang kantor adalah penyusunan atau pengaturan 
daripada perlakuan dan pegawai dalam bergerak. 3). Pewarnaan; Pewarnaan harus diperhatikan dalam sebuah lingkungan kerja, karena warna mempengaruhi jika seseorang yang ada di sekitarnya. Menata warna di tempat kerja perlu dipelajari dan direncanakan sebaik-baiknya. Pada kenyataannya tata warna tidak dapat dipisahkan dengan penataan dekorasi. Hal ini dapat dimaklumi karena warna kadangkadang menimbulkan rasa senang, sedih, dan lain-lain karena dalam sifat warna dapat merangsang perasaan manusia. 4). Penerangan; Cahaya atau penerangan sangat besar manfaatnya bagi pegawai guna mendapat keselamatan dan kelancaran kerja, oleh sebab itu perlu diperhatikan adanya penerangan (cahaya) yang terang tetapi tidak menyilaukan. Cahaya yang kurang jelas (kurang cukup) mengakibatkan penglihatan menjadi kurang jelas, sehingga pekerjaan akan lambat, banyak mengalami kesalahan, dan pada akhirnya menyebabkan kurang efisien dalam melaksanakan pekerjaan, sehingga tujuan organisasi sulit tercapai. 5). Pertukaran udara; Oksigen merupakan gas yang dibutuhkan oleh makhluk hidup untuk menjaga kelangsungan hidup, yaitu untuk proses metabolisme. Udara di sekitar dikatakan kotor apabila kadar oksigen dalam udara tersebut telah berkurang dan telah bercampur dengan gas atau bau-bauan yang berbahaya bagi kesehatan tubuh. Sumber utama adanya udara segar adalah adanya tanaman disekitar tempat kerja. Tanaman merupakan penghasil oksigen yang dibutuhkan oleh manusia. 6). Musik; Menurut para pakar, musik yang nadanya lembut sesuai dengan suasana, waktu dan tempat dapat membangkitkan dan merangsang karyawan untuk bekerja. Oleh karena itu lagu-lagu perlu dipilih dengan selektif untuk dikumandangkan di tempat kerja. Tidak sesuainya musik yang diperdengarkan di tempat kerja akan mengganggu konsentrasi kerja. 7). Tingkat kebisingan suara; Salah satu polusi yang cukup menyibukkan para pakar untuk mengatasinya adalah kebisingan, yaitu bunyi yang tidak dikehendaki oleh telinga. Tidak dikehendaki, karena terutama dalam jangka panjang bunyi tersebut dapat mengganggu ketenangan bekerja, merusak pendengaran, dan menimbulkan kesalahan komunikasi, bahkan menurut penelitian, kebisingan yang serius dapat menyebabkan kematian. 8). Hubungan atasan dengan bawahan; Hubungan sosial yang harmonis di dalam organisasi, baik antara pegawai dengan pemimpin merupakan faktor-faktor yang cukup penting dalam meningkatkan motivasi kerja pegawai. Adanya ketegangan yang muncul dalam organisasi, akan menurunkan motivasi kerja seorang pegawai, sehingga kinerjanya tidak optimal. Untuk itu, tugas seorang pemimpin adalah menciptkan hubungan kerja yang harmonis diantara para pegawai, misalnya dengan mengatasi berbagai permasalahan yang muncul diantara para pegawai, melakukan rekreasi bersama dan lain-lain. 9). Hubungan dengan rekan kerja; Hubungan dengan rekan kerja yaitu hubungan dengan rekan kerja harmonis dan tanpa ada saling intrik diantara sesama rekan sekerja. Salah satu faktor yang dapat mempengaruhi karyawan tetap tinggal dalam satu organisasi adalah adanya hubungan yang harmonis diantara rekan kerja. Hubungan yang harmonis dan kekeluargaan merupakan salah satu faktor yang dapat mempengaruhi kinerja karyawan. 10). Keamanan pada tempat kerja; Guna menjaga tempat dan kondisi lingkungan kerja tetap dalam keadaan aman maka perlu diperhatikan adanya keamanan dalam bekerja. Oleh karena itu faktor keamanan perlu diwujudkan keberadaannya. Salah satu upaya untuk menjaga keamanan ditempat kerja, dapat memanfaatkan tenaga Satuan Petugas Pengaman (SATPAM). Diharapkan terciptanya lingkungan kerja yang 
kondusif sehingga karyawan akan betah dalam bekerja."

\section{Disiplin Kerja}

Disiplin merupakan "suatu kekuatan yang berkembang di dalam tubuh pekerja sendiri yang menyebabkan dia dapat menyesuaikan diri dengan sukarela kepada keputusan-keputusan, peraturanperaturan, dan nilai-nilai tinggi dari pekerjaan dan tingkah laku". (Asmiarsih, 2006). Menurut Fathoni (2006 kedisiplinan adalah "kesadaran dan kesediaan seseorang menaati semua peraturan perusahaan dan norma-norma sosial yang berlaku". Kedisiplinan dapat diartikan bilamana karyawan selalu datang dan pulang tepat pada waktunya, mengerjakan semua pekerjaannya dengan baik, mematuhi semua peraturan perusahaan dan norma-norma sosial yang berlaku. Kedisiplinan harus ditegakkan dalam suatu organisasi perusahaan, karena tanpa dukungan disiplin karyawan yang baik maka sulit perusahaan untuk mewujudkan tujuannya. Kemudian menurut Hasibuan (dalam Barnawi, 2012), disiplin kerja adalah "kemampuan kerja seseorang untuk secara teratur, tekun, terus menerus, dan bekerja sesuai dengan aturan-aturan yang berlaku dengan tidak melanggar aturan-aturan yang sudah ditetapkan".

Berdasarkan pendapat-pendapat tersebut, dapat disimpulkan bahwa disiplin kerja karyawan merupakan sikap atau tingkah laku yang menunjukkan kesetiaan dan ketaatan seseorang atau sekelompok orang terhadap peraturan yang telah ditetapkan oleh instansi atau organisasinya baik yang tertulis maupun tidak tertulis sehingga diharapkan pekerjaan yang dilakukan efektif dan efesien.

Disiplin kerja merupakan variabel yang dipengaruhi oleh sejumlah faktor dari dalam maupun dari luar diri guru atau karyawan. Faktor dari dalam adalah persepsi terkait dengan peraturan tersebut.
Peraturan dibuat untuk mencapai tujuan. Singodimedjo (dalam Barnawi 2012) menyatakan tujuh faktor eksternal yang mempengaruhi disiplin karyawan yaitu: 1). "Kompensasi; Besar atau kecilnya kompensasi dapat dapat mempengaruhi displin kerja. Karyawan cenderung akan mematuhi segala peraturan apabila ia merasa kerja kerasnya akan mendapatkan imbalan yang sesuai dengan jerih payah yang diberikan oleh pimpinan, apabila para guru atau karyawan memperoleh kompensasi memadai, mereka akan bekerja dengan tekun disertai dengan perasaan senang. 2). Keteladanan pimpinan; Keteladanan pimpinan sangat dibutuhkan oleh setiap bawahan diorganisasi manapun. Pemimpin adalah panutan. Ia merupakan tempat bersandar bagi para bawahannya. Pemimpin yang bisa menjadi teladan akan mudah menerapkan disiplin kerja bagi karyawannya. Demikian pula sebaliknya, pemimpin yang buruk akan sulit mengadakan disiplin kerja bagi para bawahannya. Oleh karena itu, pimpinan harus dapat menjadi contoh bagi para bawahannya jika mengiginkan disiplin kerja yang sesuai dengan harapan. 3). Aturan yang pasti; Didiplin kerja tidak akan terwujud tanpa acanya aturan pasti yang dapat menjadi pedoman bagi bawahan dalam menjalankan tugasnya. Aturan yang tidak jelas kepastiannya tidak akan mungkin bisa terwujud dalam perilaku bawahan. Setiap bawahan tidak akan percaya pada aturan yang berubahubah dan tidak jelas kepastiannya. Aturan yang pasti ialah aturan yang dibuat tertulis yang dapat menjdi pedoman bagi karyawan dan tidak berubah-ubah karena situasi dan kondisi. 4). Keberanian pimpinan dalam mengambil tindakan; Apabila terdapat pelanggaran disiplin kerja, pimpinan harus memiliki keberanian untuk menyikapi sesuai dengan aturan yang menjdi pedoman bersama. Pimpinan tidak boleh bertindak diskriminasi dalam menagani pelanggaran 
disiplin kerja.

5). Pengawasan pemimpin; Pengawasan sangat diperlukan untuk memastikan segala kegiatan berjalan sesuai dengan standar peraturan. Pengawasan yang lemah memberi kesempatan bawahan melanggar peraturan. Pengawasan sangat penting mengingat sifat dasar yang ingin bebas tanpa terikat oleh aturan.

6).

Perhatian kepada para karyawan; Karyawan tidak hanya membutuhkan kompensasi yang besar, tetapi perlu juga perhatian dari atasannya. Kesulitankesulitan yang dihadap pagawai ingin didengar dan selanjutnya diberikan masukan oleh pimpinan, pimpinan yang suka memberika perhatian kepada karyawannya akan menciptakan kehangatan hubungan kerja antara atasan dengan bawahannya pimpinan yang semacam itu akan dihormati dan dihargai oleh para bawahannya. Karyawan yang segan dan hormat kepada pimpinan akan memiliki disiplin kerja yang sesungguhnya. Yaitu, disiplin kerja yang penuh kesadaran dan kerelaan dalam menjalaninya. 7). Kebiasaan-kebiasaan yang mendukung tegaknya disiplin; Kebiasaan-kebiasaan positif itu, diantaranya a). Mengucapkan salam dan berjabat tangan apabila bertemu; b). Saling menghargai antar sesama rekan; c). Saling memperhatikan antar sesama rekan; d). memberitahu saat meninggalkan tempat kerja kepada rekan".

Pada dasarnya banyak indikator yang mempengaruhi tingkat kedisiplinan karyawan suatu perusahaan, diantaranya yang disampaikan oleh Moenir (2014). Indikator - indikator yang mempengaruhi disiplin kerja: 1). "Ketepatan Waktu; Ketepatan waktu dalam pekerjaan dan tugas, meliputi: a). Ketepatan waktu dalam melaksanakan tugas. $\quad$ b). Penghematan waktu dalam melaksanakan tugas. 2). Tanggung Jawab; Tanggungjawab dalam pekerjaan dan tugas, meliputi: a). Melakukan pekerjaan sesuai dengan rencana. b).

Mengevaluasi hasil pekerjaan.

c).

Keberanian menerima resiko kesalahan. 3). Ketaatan; Ketaatan terhadap peraturan yang telah ditetapkan, meliputi: a). Ketaatan terhadap jam kerja. b). Ketaatan terhadap pimpinan.

c). Ketaatan terhadap prosedur dan metode kerja".

\section{METODE PENELITIAN}

Metode penelitian dengan menggunakan analisis deskriptif kualitatif dan kuantitatif, model analisis yang digunakan regresi linear baik secara sederhana maupun berganda. Populasi dalam penelitian ini adalah karyawan Bagian Operator SPBU Bekasi Ahmad Yani berjumlah 52 orang. Teknik pengambilan sampel dalam penelitian ini menggunakan teknik sampling jenuh, semua anggota populasi dijadikan sampel yang berjumlah 52 orang karyawan.

\section{HASIL ANALISIS DAN PEMBAHASAN}

\section{Hasil Penelitian}

\section{Uji Kualitas Data}

Berdasarkan penelitiaan data yang diperoleh, maka untuk dapat menentukan apakah benar variabel lingkungan kerja dan disiplin kerja dapat dijadikan pengukur terhadap produktivitas kerja karyawan Bagian Operator SPBU Bekasi PT. Pertamina Retail, namun sebelum data diolah terlebih dahulu dilakukan pengujian terhadap variabel yang di gunakan yaitu lingkungan kerja, disiplin kerja dan produktivitas kerja untuk mengetahui apakah data tersebut akurat dan dapat dipercaya. Untuk lebih jelasnya maka dibawah ini dapat kita lihat hasil dari survey, sebagai berikut:

\section{Uji Validitas}

Penguji validitas ini dilakukan untuk menguji apakah tiap-tiap butir 
pernyataan telah mewakili indikator yang akan diselidiki. Validitas pengukuran tersebut dapat dilihat dengan bantuan software SPSS. Ver.26.0 Menurut Sugiyono (2016), menyatakan bahwa biasanya syarat minimum untuk dianggap valid adalah $r=0,30$. Jadi apabila korelasi antara butir-butir dengan skor total kurang dari 0,30 maka butiran dalam instrumen tersebut dinyatakan tidak valid. Uji validitas dilakukan dengan melihat korelasi skor masing-masing butir pernyataan dengan skor total.

\section{Uji Validitas Intrumen Data}

Dari hasil perhitungan korelasi skor tiap butir pernyataan lingkungan kerja, disiplin kerja dan produktivitas kerja dari 52 responden dengan jumlah butir pernyataan sebanyak 10 untuk variabel lingkungan kerja, 9 butir pernyataan untuk variabel disiplin kerja dan 10 butir pernyatan untuk variabel produktivitas kerja dengan total skor setiap responden diperoleh hasil nilai $r$ hitung lebih besar dari $r$ kritis 0,300. Dengan demikian dapat disimpulkan hasilnya adalah valid.

\section{Uji Reliabilitas}

Pengujian reliabilitas ini dilakukan untuk menguji seberapa jauh hasil pengukuran yang dapat diandalkan secara konsisten. Pada tabel hasil pengujian reliabilitas berikut, diketahui bahwa semua variabel mempunyai alpha di atas 0,6 yang berarti bahwa semua variabel dalam penelitian ini dapat diandalkan.

Tabel 1: Hasil Uji Reliabilitas Variabel

\begin{tabular}{lcc}
\hline \multicolumn{1}{c}{ Variabel } & Cronbach's Alpha & Keterangan \\
\hline Lingkungan Kerja & 0.672 & Reliabel \\
Disiplin Kerja & 0.773 & Reliabel \\
Produktivitas Kerja & 0.757 & Reliabel \\
\hline
\end{tabular}

Sumber: Hasil pengolahan data, 2020

Berdasarkan Tabel 1, angka-angka reliabilitas cronbach alpha tersebut tampak bahwa seluruh pernyataan yang ada membentuk ukuran yang reliabel, yaitu lingkungan kerja, disiplin kerja, dan produktivitas kerja membentuk ukuran yang reliabel dari masing-masing variabel.

\section{Analisis Hasil Penelitian}

Tabel 2: Pengaruh Lingkungan Kerja Terhadap Produktivitas Kerja

\begin{tabular}{lccccc}
\hline \multirow{2}{*}{ Variabel } & $\begin{array}{c}\mathbf{R} \\
\text { Square }\end{array}$ & Konstanta & $\begin{array}{c}\text { Koefisien } \\
\text { Regresi }\end{array}$ & Sig & $\boldsymbol{\alpha}$ \\
\hline Ling_Kerja & 0,681 & 10,942 & 0,811 & 0,000 & 0,01 \\
\hline Pengujian Signifikan & & & & \\
\hline t hitung $>$ t tabel $=10,336>2,009$ & & & & \\
\hline
\end{tabular}

Keterangan: Variabel Produktivitas Kerja

Sumber: data diolah 2020

Berdasarkan Tabel 2, nilai koefisien determinasi $\left(\mathrm{R}^{2}\right)$ sebesar 0.681 , artinya lingkungan kerja memberikan kontribusi sebesar $68,1 \%$ kepada produktivitas kerja karyawan Bagian Operator SPBU Bekasi
PT Pertamina Retail, sedangkan sisanya sebesar 31,9\% disumbangkan faktor lain yang tidak diteliti. 
Persamaan Regresi $\mathrm{Y}=10,942+0,811$ $\left(\mathrm{X}_{1}\right)$

Lingkungan kerja berpengaruh positif dan signifikan pada tingkat nyata 99\% terhadap produktivitas kerja karyawan Bagian Operator SPBU Bekasi PT Pertamina Retail. Koefisien lingkungan kerja sebesar 0,811 , artinya jika ada peningkatan lingkungan kerja, maka produktivitas kerja karyawan Bagian Operator SPBU Bekasi PT Pertamina Retail akan meningkat atau sebaliknya.

Tabel 3: Pengaruh Disiplin Kerja Terhadap Produktivitas Kerja

\begin{tabular}{lccccc}
\hline \multirow{2}{*}{ Variabel } & $\begin{array}{c}\text { R } \\
\text { Square }\end{array}$ & Konstanta & $\begin{array}{c}\text { Koefisien } \\
\text { Regresi }\end{array}$ & Sig & $\boldsymbol{\alpha}$ \\
\hline Disiplin Kerja & 0,591 & 13,042 & 0,804 & 0,000 & 0.01 \\
\hline Pengujian Signifikan & & & & \\
\hline t hitung > t tabel $=8,500>2,009$ \\
\hline Keterangan: Variabel Produktivitas Kerja \\
Sumber: data diolah 2020
\end{tabular}

Berdasarkan Tabel 3, nilai koefisien determinasi $\left(\mathrm{R}^{2}\right)$ sebesar 0.591 , artinya disiplin kerja memberikan kontribusi sebesar 59,1\% kepada produktivitas kerja karyawan Bagian Operator SPBU Bekasi PT Pertamina Retail, sedangkan sisanya sebesar 40,9\% disumbangkan faktor lain yang tidak diteliti.

Persamaan Regresi $\mathrm{Y}=13,042+0,804$ $\left(\mathrm{X}_{2}\right)$
Disiplin kerja berpengaruh positif dan signifikan pada tingkat nyata $99 \%$ terhadap produktivitas kerja karyawan Bagian Operator SPBU Bekasi PT Pertamina Retail. Koefisien disiplin kerja sebesar 0,804, artinya jika ada peningkatan disiplin kerja, maka produktivitas kerja karyawan Bagian Operator SPBU Bekasi PT Pertamina Retail akan meningkat atau sebaliknya.

Tabel 4: Pengaruh Lingkungan Kerja dan Disiplin Kerja Terhadap Produktivitas Kerja

\begin{tabular}{lccccc}
\hline \multirow{2}{*}{ Variabel } & $\begin{array}{c}\text { R } \\
\text { Square }\end{array}$ & Konstanta & $\begin{array}{c}\text { Koefisien } \\
\text { Regresi }\end{array}$ & Sig. & $\boldsymbol{\alpha}$ \\
\cline { 2 - 6 } & 0,707 & 9,052 & 0,585 & 0,000 & 0,001 \\
\hline Ling_Kerja & & & & & \\
Disiplin Kerja & & & & & \\
\hline Pengujian Signifikan & & & & \\
\hline F hitung > F tabel = 59,054 > 3,187 \\
\hline Keterangan: Variabel Produktivitas Kerja \\
Sumber: data diolah 2020
\end{tabular}

Berdasarkan Tabel 4, nilai $\mathrm{F}$ hitung $>$ F tabel $(59,054>3,187)$, maka Ho tolak, Ha terima, artinya lingkungan kerja dan disiplin kerja berpengaruh signifkan pada tingkat nyata $99,0 \%$ terhadap produktivitas kerja karyawan Bagian Operator SPBU Bekasi PT Pertamina
Retail. Nilai koefisien determinasi $\left(\mathrm{R}^{2}\right)$ sebesar 0.707 , artinya lingkungan kerja dan disiplin kerja secara bersama-sama memberikan kontribusi sebesar 70,7\% kepada produktivitas kerja karyawan Bagian Operator SPBU Bekasi PT Pertamina Retail, sedangkan sisanya 
sebesar 29,3\% disumbangkan faktor lain yang tidak dibahas dalam penelitian ini.

Persamaan Regresi $\mathrm{Y}=9,052+0,585\left(\mathrm{X}_{1}\right)$ $+0,293\left(\mathrm{X}_{2}\right)$

Lingkungan kerja dan disiplin kerja berpengaruh positif dan signifikan terhadap produktivitas kerja karyawan Bagian Operator SPBU Bekasi PT Pertamina Retail pada tingkat nyata $99 \%$. Koefisien lingkungan kerja sebesar 0,585 , artinya jika ada peningkatan lingkungan kerja, maka produktivitas kerja karyawan Bagian Operator SPBU Bekasi PT Pertamina Retail akan meningkat atau sebaliknya dengan asumsi disiplin kerja tidak berubah. Koefisien disiplin kerja sebesar 0,293, artinya jika ada peningkatan disiplin kerja, maka produktivitas kerja karyawan Bagian Operator SPBU Bekasi PT Pertamina Retail, akan meningkat atau sebaliknya, dengan asumsi lingkungan kerja tidak berubah.

\section{Pembahasan}

\section{Pengaruh Lingkungan Kerja Terhadap Produktivitas Kerja Karyawan Bagian Operator SPBU Bekasi PT Pertamina Retail}

Hasil penelitian ini menunjukkan bahwa lingkungan kerja yang baik dapat mendorong peningkatan produktivitas kerja karyawan. Hal ini dikarenakan bahwa lingkungan kerja yang bersih dan ramah lingkungan, pengaturan ruang kantor mempengaruhi aktivitas kerja, warna ruang kantor menimbulkan rasa senang, penerangan ruangan sangat besar manfaatnya, pertamina berusaha menekan emisi terhadap lingkungan kerja, musik yang nadanya lembut dapat membangkitkan kerja, bunyi yang tidak dikehendaki mengganggu ketenangan bekerja, menciptakan iklim kerja yang sehat dan mendukung kesejahteraan karyawan, salimg membantu jika mengalami kesulitan dalam pekerjaan, dan karyawan sangat memperhatikan aspek-aspek K3 dalam bekerja. Hasil penelitian ini sesuai dengan penelitian yang dilakukan oleh Albaqami. (2015) dan Al-Shammari, (2013), yaitu menganalisis pengaruh lingkungan kerja terhadap produktivitas kerja karyawan. Dengan demikian hipotesis pertama dapat diterima.

\section{Pengaruh Disiplin Kerja Terhadap Produktivitas Kerja Karyawan Bagian Operator SPBU Bekasi PT Pertamina Retail}

Hasil penelitian ini menunjukkan bahwa disiplin kerja mendorong peningkatan produktivitas kerja karyawan. Hal ini dikarenakan bahwa karyawan tepat dalam melaksanakan tugas, dapat menghemat waktu, cepat dalam melayani konsumen, pekerjaan dikerjakan sesuai dengan rencana, karyawan diminta mengevaluasi hasil kerjanya, karyawan berani menerima resiko atas kesalahannya, kehadiran kerja karyawan sesuai dengan jam kerja, tidak mentati peraturan diberikan sanksi, dan mengikuti semua peraturan yang telah ditetapkan perusahaan. Hasil penelitian ini sejalan dengan penelitian yang dilakukan oleh Thamrin, et al, (2015) dan Aspiyah \& Martono, (2016). yaitu menganalisis pengaruh disiplin kerja terhadap prduktivitas kerja karyawan. Dengan demikian hipotesis kedua dapat diterima.

Pengaruh Lingkungan Kerja dan Disiplin Kerja Terhadap Produktivitas Kerja Karyawan Bagian Operator SPBU Bekasi PT Pertamina Retail

Berdasarkan hasil analisis diketahui bahwa lingkungan kerja dan disiplin kerja mendorong peningkatan produktivitas kerja karyawan Bagian Operator SPBU Bekasi PT Pertamina Retail. Hasil penelitian ini sama dengan hasil penelitian 
yang dilakukan oleh Reski, et al. (2015), Suprapto, (2016), Thamrin, et al, (2015) dan Aspiyah \& Martono, (2016), yaitu menganalisis pengaruh lingkungan kerja dan disiplin kerja terhadap produktivitas kerja karyawan. Dengan demikian hipotesis ketiga dapat diterima.

\section{KESIMPULAN DAN SARAN}

\section{Kesimpulan}

Dari hasil analisis dan pembahasan yang tertuang, dapat diambil kesimpulan bahwa: 1). Lingkungan kerja mendukung peningkatan produktivtas kerja karyawan Bagian Operator SPBU Bekasi PT Pertamina Retail. 2). Disiplin kerja dapat mendukung peningkatan produktivtas kerja karyawan Bagian Operator SPBU Bekasi PT Pertamina Retail.

Lingkungan kerja dan disiplin kerja secara bersama-sama mendukung peningkatan produktivtas kerja karyawan Bagian Operator SPBU Bekasi PT Pertamina Retail.

\section{Saran}

Berdasarkan analisis dan pembahasan pengujian secara empiris suatu kesimpulan yang dikemukakan di atas, Peneliti pada sub bagian ini mencoba memberikan rekomendasi atau saran yang mungkin dapat ditindaklanjuti oleh PT. Pertamina Retail sebagai berikut: 1). Lingkungan kerja sudah baik, pertamina sudah memperhatikan lingkungan kerja disemua SPBU yang berada dalam lingkungannya, namun untuk lebih menjaga lingkungan lebih baik lagi kiranya tetap mempertahankan yang sudah ada kemudian lebih diperhatikan dan ditingkatkan masalah hubungan kerja sesama rekan kerja, serta perhatikan perlengkapan kerja karyawannya. 2). Disiplin kerja karyawan sudah relatif baik, karyawan hadir sesuai dengan waktu yang ditetapkan, tanggung jawab terhadap pekerjaan dapat dipercaya, ketaatan mengikuti aturan dan patuh terhadap perintah pimpinan, ini semua dilaksanakan dengan baik. Sebagai masukan kiranya perusahaan melalui pimpinan terus lebih mengawasi aktifitas karyawan dan selalu berikan arahanarahan yang dapat meningkatkan kinerja karyawan. 3). Bagi peneliti selanjutnya disarankan untuk menambah variabelvariabel lain yang lebih beragam dalam membahas yang berkaitan dengan produktivitas kerja karyawan dalam perusahaan yang bergerak dibidang di bidang ritel khususnya penyaluran bahan bakar di SPBU.

\section{DAFTAR PUSTAKA}

Albaqami, Talal. 2015. "Working Environment and Productivity". International Journal of Scientific \& Engeneering Research, Volume 6, Issue 12, Desember 2015. ISSN: 2229-5518. Hal. 710-713.

Al-Shammari, Serhan. 2013. "The Effect of Work Environment on Employees' Productivity". International Journal of Science and Research (IJSR). ISSN (online): 2319-7064. Index Copernicus Value (2013): 6-14 Impac Factor (2013): 4.438 .

Asmiarsih T. 2006. Pengaruh Pengawasan Terhadap Disiplin Kerja pegawai Badan Kepegawaian Daerah Kabupaten Brebes. [Skripsi]. Semarang: Fakultas Ilmu Sosial. Universitas Negeri Semarang.

Aspiyah dan Martono. 2016. "Pengaruh Disiplin Kerja, Lingkungan dan Pelatihan Terhadap Produktivitas Kerja”. Management Analysis Journal 5 (4) (2016). ISSN: 22526552. Hal. 339-346

Barnawi dan Muhammad Arifin. 2012. Etika \& Profesi Kependidikan. Yogyakarta: Ar-Ruz Media, 2012.

Basuki dan Susilowati. 2005. Organisasi 
dan Motivasi: Dasar Peningkatan Produktivitas. Jakarta: Cetakan Pertama, Bumi Askara.

Fathoni, Abdurahmat. 2006. Organisasi dan Manajemen Sumber Daya Manusia. Jakarta: Rineka Cipta.

Hasibuan, Malayu. 2012. Manajemen Sumber Daya Manusia. Jakarta: PT. Bumi Aksara.

Komaruddin. 2006. Manajemen Sumber Daya Manusia. Bandung: KappaSigma.

Moenir, H.A.S. 2014. Manajemen Pelayanan Umum Di Indonesia. Jakarta: Bumi Aksara.

Nitisemito, Alex S. 2014. Manajemen Personalia. Jakarta: Ghalia Indonesia.

Reski., Marnis dan Hamid, Liswar. 2015. "Pengaruh Lingkungan Kerja dan Disiplin Terhadap Produktivitas Kerja Karyawan Pada PT. Rigunas Agri Utama Kabupaten Indragiri Hulu". JOM FEKOM Vol. 2 No. 1 Februari 2015. Hal. 1-15.

Rivai, Veithzal ZS. 2015. Manajemen Sumber Daya Manusia Untuk Perusahaan. Edisike-7. Depok: PT Rajagrafindo.

Robbins, S. 2008. Perilaku Organisasi, Jilid I dan II, alih Bahasa : Hadyana Pujaatmaja. Jakarta: Prenhallindo.

Sedermayanti. 2017. Manajemen Sumber Daya Manusia. Bandung: PT. Refika Aditama.
Siagian. Sondang P. 2012. Manajemen Sumber Daya Manusia Jakarta: Bumi Aksara.

Simanjuntak, Payaman J. 2011. Manajemen Evaluasi Kinerja . Edisi 3. Jakarta: Fakutas UI.

Singodimedjo, Markum. 2010. Manajemen Sumber Daya Manusia. Surabaya: Penerbit SMMA.

Sinungan, Muchdarsyah. 2011. Produktivitas Apa dan Bagaimana, Jakarta: Bumi Aksara.

Sugiyono. 2016. Statikstika Untuk Penelitian. Bandung : Penerbit Alfabeta.

Suprapto, Ribut. 2016. "Pengaruh Disiplin Kerja dan Lingkungan Kerja Terhadap Produktivitas Kerja Karyawan Bank BRI Syariah Kantor Cabang Pembantu Genteng Banyuwangi”. Jurnal Hukum Islam, Ekonomi dan Bisnis. Vol. 2/No. 2: 104-113, Juli 2016, ISSN: 24600083.

Sutrisno, Edy. 2016. Manajemen Sumber Daya Manusia. Jakarta: Kencana Prenada Media Group.

Thamrin, Edy., Machasin dan Sjahruddin. 2015. "Pengaruh Lingkungan Kerja, Disiplin dan Motivasi Terhadap Produktivitas Kerja Karyawan Bagian Produksi PT. Sinar Siak Dian Permai Bandar Sekijang Pelalawan". JOM FEKOM Vol. 1 No. 2 Februari 2015. Hal. 1-15 